\title{
THE CACAO FLOWER VISITOR INSECTS DIVERSITY AND THEIR POTENTIALITIES AS POLLINATORS
}

\author{
SamsuriTarmadja. \\ Agricultural Faculty of Stiper Agricultural University, Yogyakarta. \\ E-mail: Samsuri.tarmadja@gmail.com
}

\begin{abstract}
The cacao flower is beautiful, but small in size, unique in another way, and it has no smell. There a reason that bees do not attracted for pollinating the cacao flowers. Study on the diversities of flower visitor insects and their potentialities as pollinators was conducted on smallholder cacao plantations at GumawangPuthat village, Pathuksubdistrict of Gunungkidul in October 2012 to January 2013. First, field observations on 10 open flowers per plant and 10 plants per period. Second, we placed yellow paper sticky-traps on flowering sections of cacao trunks, collecting insects that became entangled. The results showed that eight species of insects visited cacao flowers. The largest populations occur in the rainy season. Aphid Toxopteraaurantii, mealy bug Planococcuslilacinus, black ants (Dolichoderusbituberculatus), Crematogaster ants and ngangrang (Anoplolepislongipes), were common cacao flower visitor, but not all role as pollinators. Aphid was potential as pollinator for self compatible clones. Mealy bug infested as pest on cushion and stalk of flower. Black ants, Crematogaster ants, and ngangrangas symbionts of aphids and mealy bug and also no act as pollinators. Drosophila flies as flower visitors, but only outside sepal and not into the petal sac and style. Only midges Cecidomyiid and Ceratopogonid were potential as pollinators, due to the body size, character of morphology and activity in the flower were proportionate as pollinator.
\end{abstract}

Key words: Insect diversity, visitor and pollinator, cacao

\section{INTRODUCTION}

Pollination is a free ecological service. In order to sustain pollinator services associated with agricultural ecosystems, far more understanding is needed of the multiple goods and services provided by pollinator diversity. Cacao (Theobromacacao L.) is a cauliflorous tree and produces a surplus flowers (Glendenning, 1972), of whichgenerally no more than $5 \%$ develop into mature fruits (Entwistle, 1972; Young, 1994). The cacao flower is strictly entomophilous (Fimprong, 2011), but small in size, unique in another way, and it has no smell. There a reason that bees do not attracted for pollinating the cacao flowers.

The objectives of this study were to determine the diversities of flower visitor insects and their potentialities as pollinators on smallholder cacao plantations. It is necessary to identify adaptive management practices that minimize negative impacts by humans on pollinators, promote the conservation and diversity of native pollinators, and conserve and restore natural areas necessary to optimize pollinator services in cacao plantation.

\section{MATERIALS AND METHODS}

Research was conducted on smallholder cacao plantations at Gumawang-Puthat village, Pathuksubdistrict of Gunungkidul in October 2012 to January 2013. First, field observations on 10 open flowers per plant and 10 plants per period. Second, we placed yellow paper sticky-traps on flowering sections of cacao trunks, collecting insects that became entangled. 


\section{RESULTS AND DISCUSSION}

The results showed that eight species of insects visited cacao flowers. The insect populations were lowly at October - November. The largest populations occur in the early rainy season on January. Aphids Toxoptera aurantii, mealybugs Planococcus lilacinus, black ants (Dolichoderus bituberculatus), Crematogaster ants and ngangrang (Anoplolepis longipes), were common cacao flower visitor, but not all role as pollinators.

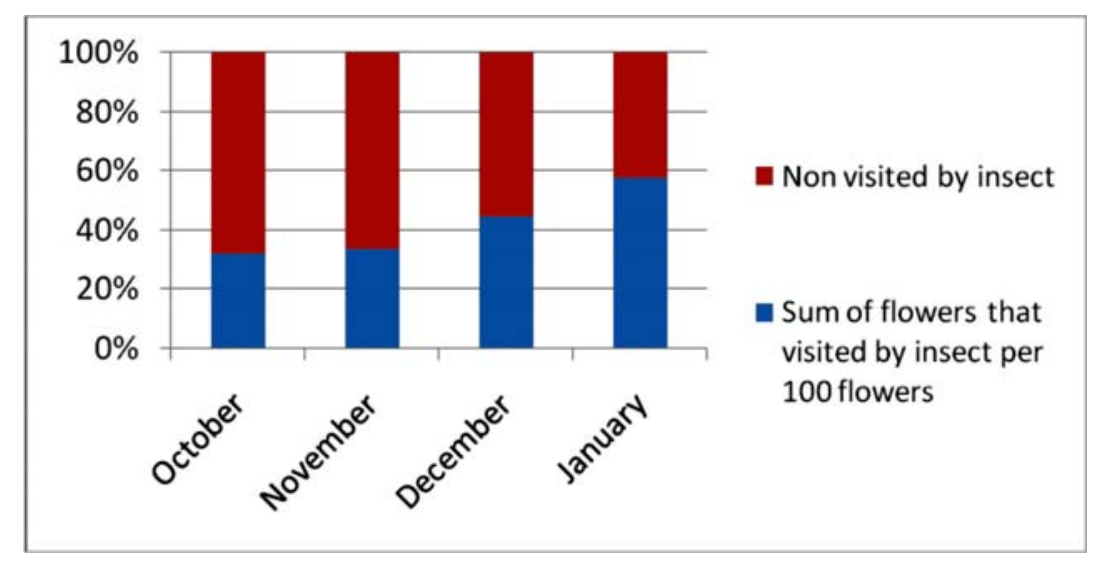

Figure 1.Sum of flower visited by insect per 100 opened flowers.

Aphid colonies usually found feeding on underside of young leaves, on succulent stem of chupons and on the stalk of flowers. The wingless form usually predominates. It was potential as pollinator for self compatible clones only due to the sedentary behavior of aphids. According to Susilo (2006), that most cacao varieties are self incompatible, and are thus dependent on cross-pollination.

Mealybugs may be found infested as pest on unripe pods, on the angles of newer branches, flower cushion and flower stalks. They are usually considered to be relatively immobile and not role as pollinator. Black ants (D. bituberculatus), Crematogaster ants, and ngangrangas symbionts of aphids and mealybugs and also no act as pollinators. Drosopholid flies as flower visitors, but only outside sepal and not into the petal sac and style.

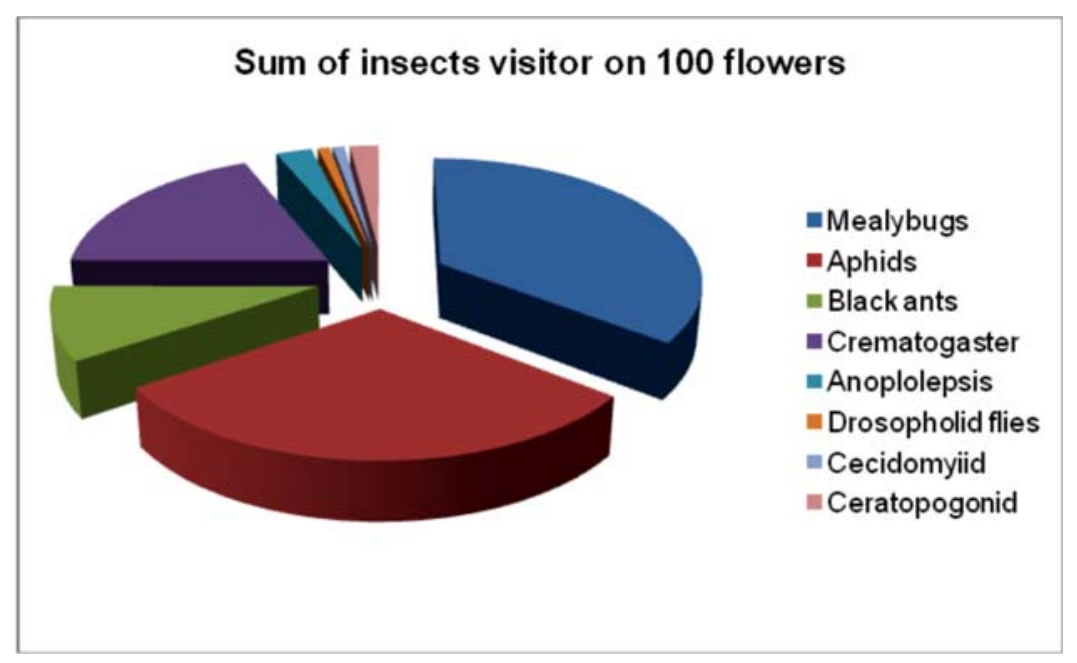

Figure 2. Sum of insects visitor on 100 opened flowers 
The flying insect midges Cecidomyiidae and Ceratopogonidae were potential as pollinators, due to the body size, character of morphology and avtivity in the flower were proportionate as pollinator, but flower-visiting and pollinating species of ceratopogonidand cecidomyiidare not identified to the species level.

\section{CONCLUSION}

The results showed that eight species of insects visited cacao flowers areaphid Toxoptera aurantii, mealy bug Planococcuslilacinus, black ants (Dolichoderus bituberculatus), Crematogaster ants and ngangrang (Anoplolepis longipes), drosopholid flies, but only midges cecidomyiid and ceratopogonid were potential as economic pollinators.

\section{REFERENCE}

Crane, J.H., C.F. Balerdi, and G. Joyner. 2009. Cocoa (Chocolate Bean) Growing in the Florida Home Landscape. HS1057 document of a series of the Horticultural Sciences Department, Florida Cooperative Extension Service, Institute of Food and Agricultural Sciences, University of Florida.

Frimpong, E.A., I. Gordon, P.K. Kwapong and B. Gemmill-Herren. 2009. Dynamics of cocoa pollination: tools and applications for surveying and monitoring cocoa pollinators. International Journal of Tropical Insect Science, 29: 62-69

Frimpong, E.A., B.G. Herren, I. Gordon and P.K. Kwapong. 2011. Dynamics of Insect Pollinators as Influenced By Cocoa Production System in Ghana. Journal of Pollination Ecology, 5(10): 74-80

Free, J. B. 1993. Insect Pollination of Crops. Chapter 65. Academic Press, London, UK. Glendinning, D.R. 1971. Natural pollination of cocoa. New Phytologist71:719-729.

Groeneveld, J.H., T. Tscharntke, G. Moser, and Y. Clough. 2010. Experimental evidence for stronger cacao yield limitation by pollination than by plant resources. Perspect. Plant Ecol. Evol. and Systematics doi:10.1016/j.ppees.2010.02.005.

Kaufmann, T. 1975. Studies on the ecology and biology of a cocoa pollinator, Forcipomyia squamipennis I. \& M. (Diptera, Ceratopogonidae), in Ghana, Bulletin Entomological Research 65: 263-268

Larson, B.M.H., P. G. Kevan and D. W. Inouye. 2001. Flies and flowers: The taxonomic diversity of anthophiles and pollinators. Canadian Entomologist 133(4): 439-465.

Ludwiq, J.A., and J. F. Reynolds. 1988. Statistical Ecoloqy a Primer on Methods and Computing. John Wiley \& Sons, New York

Odum, E.P. 1994. Dasar-dasar Ekologi. Gadjah Mada University Press. Yogyakarta.

Symank, A., C.A. Kearns, T.H. Pape, and F.C. Thomson. 2008. Pollinating Flies (Diptera): A major contribution to plant diversity and agricultural production. Tropical Conservancy 9 (1 \& 2): 86-89.

Susilo, A.W. 2006. Self-compatibility crosses of several cocoa clones. Kemampuan menyerbuk sendiri beberapa klon kakao (Theobroma cacao L.). Pelita Perkebunan. ISSN 0215-0212 (2006) v. 22(3) p. 159-167

Winder, J. A. 1977. Some organic substrates which serve as insect breeding sites in Bahian cocoa plantations. Review of Brazilian Biology 37: 351-356. 
Winder, J.A. 1978. Cocoa Flower Diptera, Their Identity, Pollinating Activity and Breeding Sites. PANS 24 (1): 5 - 18.

Young, A. M. 1982. Effect of shade cover and availability of midge breeding sites on Pollinating midge populations and fruit set in two cacao farms Journal Applied Ecology 19: 149155.

Young, A. M. 2007. The Chocolate Tree, A Natural History of Cacao.Gainsville: University Press of Florida. 